\title{
Homonymous Hemianopsia Detected During a Meal
}

\author{
Kotaro Noda ${ }^{1,2}$, Yorito Hattori ${ }^{1}$ and Masafumi Ihara ${ }^{1}$
}

Key words: homonymous hemianopsia, cerebral infarction, meal, daily living

\author{
(Intern Med Advance Publication)
}

(DOI: 10.2169/internalmedicine.9147-21)

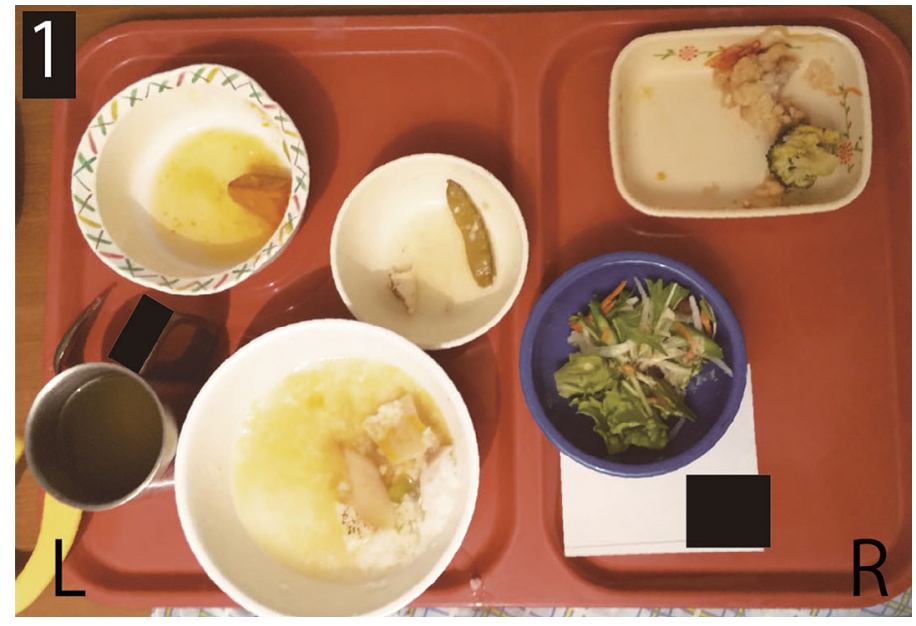

Picture 1.
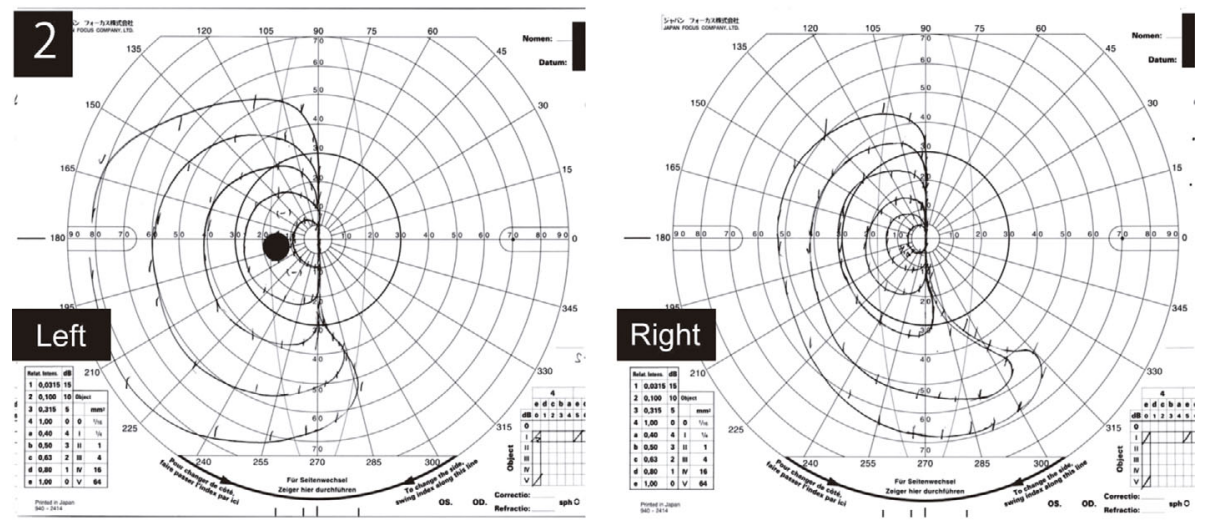

Picture 2.

During dinner, a 74-year-old man ate food only from the left side of the dish, leaving the right side untouched (Picture 1). The Goldmann visual field record revealed right homonymous hemianopsia (HH) (Picture 2), and diffusionweighted magnetic resonance imaging showed acute cerebral infarction in the left thalamus and occipital lobe (Picture 3). Most cases of $\mathrm{HH}$ are induced by ischemic stroke (1), and approximately half of these cases are not self-detected by such patients in daily life (2). Early intervention using intravenous recombinant tissue plasminogen activator (rtPA) and

${ }^{1}$ Department of Neurology, National Cerebral and Cardiovascular Center, Japan and ${ }^{2}$ Department of Neurology and Neurological Science, Graduate School of Medical and Dental Sciences, Tokyo Medical and Dental University, Japan

Received: December 5, 2021; Accepted: January 4, 2022; Advance Publication by J-STAGE: February 19, 2022

Correspondence to Dr. Yorito Hattori, yoh2019@ncvc.go.jp 


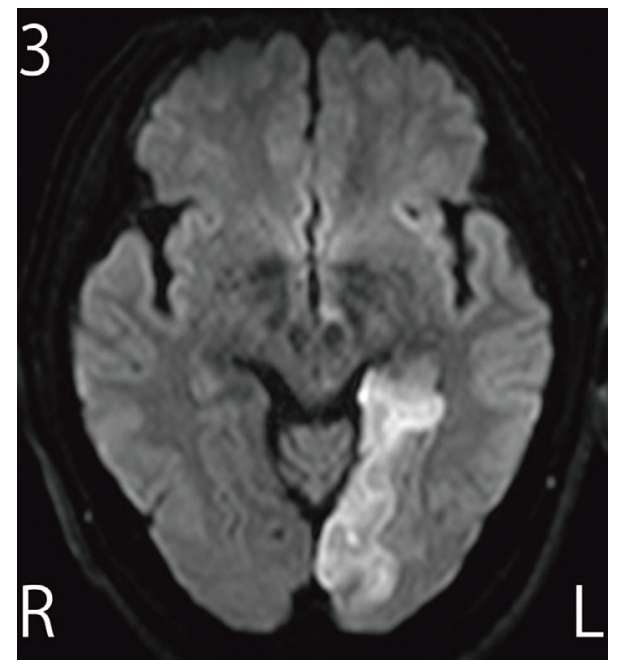

Picture 3.

mechanical thrombectomy has been identified as an important factor in the functional outcome of patients with ischemic stroke. For example, rtPA should be administered within $4.5 \mathrm{~h}$ of the stroke onset. Our findings will be aid family practitioners and caregivers in detecting and understanding the symptoms of $\mathrm{HH}$, thereby contributing to good functional outcomes in these patients.

The authors state that they have no Conflict of Interest (COI).

\section{References}

1. Jorge $\mathrm{CB}$, Vanessa $\mathrm{CN}$, Miguel $\mathrm{AB}$, Irene GO, Antonio A. Prognostic Factors for Long-Term Recovery of Homonymous Visual Field Defects After Posterior Circulation Ischemic Stroke. J Stroke Cerebrovasc Dis 30: 105924, 2021.

2. Costela FM, Sheldon SS, Walker B, Woods RL. People with Hemianopia Report Difficulty with TV, Computer, Cinema Use, and Photography. Optom Vis Sci 95: 428-434, 20.

The Internal Medicine is an Open Access journal distributed under the Creative Commons Attribution-NonCommercial-NoDerivatives 4.0 International License. To view the details of this license, please visit (https://creativecommons.org/licenses/ by-nc-nd/4.0/).

(C) The Japanese Society of Internal Medicine Intern Med Advance Publication 